\title{
Faces of Modernity in Romanian Literature: A Conceptual Analysis
}

FACES DA MODERNIDADE NA LITERATURA ROMENA:

UMA ANÁLISE CONCEITUAL

Andrei Terian

Universidade Lucian Blaga

Sibiu, Romênia

\begin{abstract}
This study analyses the manner in which Romanian criticism chose to define and outline literary modernity. From this point of view, I have highlighted a series of deficiencies in the aforementioned endeavors, among which the reductive vision on modernism, which is limited either to a strictly formal meaning (as literary technique) or to a substantial one (as ideological attitude), the emergence of a non-differentiated concept of modernism, which tends to embrace any secondary effects or, on the contrary, of a generic anti-modernism, irrespective of the level or the direction in which it opposes modernism. Therefore, the present study sets forth a new classification of Romanian literary modernity, which includes, besides modernism, an anti-modernist direction and an ultra-modernist one also.
\end{abstract}

\section{Resumo}

O presente estudo analisa o modo com o qual a crítica romena decidiu definir e delinear o perfil da modernidade literária. Desse ponto de vista, sublinhei uma série de deficiências em tais esforços, dentre as quais a visão redutora do modernismo, que é limitada, seja a um sentido estritamente formal (como técnica literária), seja a um sentido substancial (como atitude ideológica), bem como o surgimento de um conceito não-diferenciado de modernismo, que tende a abraçar qualquer efeito secundário, ou pelo contrário, de um anti-modernismo genérico, independente do nível ou direção na qual se opóe ao modernismo. Consequente-

\section{Résumé}

Cette étude analyse la manière dont la critique roumaine a choisi de définir et mettre en relief la modernité littéraire. De ce point de vue, j'ai mis en évidence une série de lacunes impliquées par ce choix, dont la vision réductrice sur le modernisme, qui est limité soit à un sens strictement formel (en tant que technique littéraire) soit à un sens substantiel (entant qu'attitude idéologique), aussi bien que l'émergence d'un concept non-différenciée de modernité, qui tend à embrasser tous les effets secondaires ou, au contraire, d'un antimodernisme générique, quel que soit le niveau ou la direction dans laquelle il s'oppose à la modernité.
Keywords: modernity, Romanian literature, modernism, anti-modernism, ultramodernism

Palavras-chave: modernidade; literatura romena; modernismo; anti-modernismo; ultra-modernismo.

Mots-clés: modernité, littérature roumaine, modernisme, anti-modernisme, ultra-modernisme 
mente, o artigo propóe uma nova classificação da modernidade literária romena, que inclui, além do modernismo, uma direção antimodernista bem como uma outra ultra-modernista.
Par conséquent, cette étude présente une nouvelle classification de la modernité littéraire roumaine, qui comprend, outre le modernisme, un biais antimoderniste et un biais ultra-moderne aussi.

This study analyzes at the way in which the most important Romanian literary critics, historians and theorists of the last century have defined and applied the concept of modernism and its derivatives ${ }^{1}$ in Romanian literature; at the same time, it sets forth an alternative outline of Romanian modernism. I find that the issue of my concern has a capital importance, because, from a certain point of view, the entire history of Romanian literature fuses with the history of its modernization. This literature took shape as an institutionalized cultural practice only at the beginning of the $19^{\text {th }}$ century; its prehistory, however, gathers approximately three centuries, starting from the confirmation of the first Romanian written text, i.e. the famous letter of Neacsu of Campulung (1521). Nevertheless, with several exceptions, ${ }^{2}$ by the 1830 s, when the first de facto literary magazines, programmes and directions appear in Romania, this "literature" had meant mainly a heterogeneous group of mostly historical and religious texts. It is only in the first half of the $19^{\text {th }}$ century, when Romania's westernization begins, given the great European powers' increased interest in the Balkans' geopolitical area and owing to the circulation in the region of the various (post)Enlightenment ideologies - human rights, social emancipation, nationalism, autonomy of art, etc. - that Romanian literature becomes a defined discursive practice, as we understand it today. In fact, this process can be tracked by two tendencies: the nationalization of literature (which enables the formation of a Romanian

\footnotetext{
${ }^{1}$ The "derivatives" of modernism mean, for my approach, mainly anti-modernism and ultra-modernism, but they exclude postmodernism. Contrary to Matei Calinescu's classical thesis (CALINESCU, Matei. Five Faces of Modernity: Modernism, Avant-garde, Decadence, Kitsch, Postmodernism. Durham: Duke University Press, 1987), I believe that postmodernism is a novel socio-cultural stage in relation to modernity rather than a mere "face" of it.

${ }^{2}$ Referring mainly to the allegorical novel Istoria ieroglificăl The Hieroglyphic History by the humanist Dimitrie Cantemir (the novel was written in 1705, but published only in 1883) and Ion Budai-Deleanu's comic epopee Tiganiadal The Gypsiad (written in 1812 and published only in 1875).
} 
literature as distinct cultural system in relation to other literatures and to the works translated into Romanian) and its aestheticization (which allowed the formation of a Romanian literature as specific discourse). ${ }^{3}$ Not at all by chance, these processes overlapped the formation of two cultural and ideological poles which were not typical to Romania only, but also to the whole of Eastern Europe and, even more, to all of the (semi)peripheral cultures: the (generally "modernist") Westernizers, who defended the linking of the national culture to the flow of European intellectual life, and the (generally traditionalist) "autochtonizers" who strove for the preservation of the stable values of the "national character". Irrespective of the side taken, both tendencies (to a certain extent, still existing in present-day Romania, given fast-tracked globalization and the aggravation of identity-related dilemmas) shared a common ground that envisaged literature as a privileged battlefield for the preservation of identity, of culture and even of the Romanian national state.

For this reason, in Romania, the issue of literary modernization - and, thus, the position of modernism - has represented more than an aesthetic dilemma; it has also meant a defining indicator of its stage of sociocultural growth, of its identity cohesion and, last but not least, of its situation in the international context. It has been at the heart of all the Romanian public debates of the last two centuries, starting from the conflict between the Bonjouristes (young men educated in Paris or other Western centers) and the Tombateres (defenders of Oriental mentalities) in the 1830s and ending with the recent confrontations between the adepts of European integration and the various Euro-skeptical ideologies. Given these circumstances, the shortcomings and ambiguities that, as the present study shall demonstrate, are currently governing the definition of Romanian literary modernism are no less than a startling phenomenon. Indeed, modernism (as literary movement) cannot be mistaken for modernity (as socio-historical condition) and, least of all, for modernization (as pattern of development). It is equally true, however, that, in a culture that, at least until the collapse of communism (1989), had had a more or less literature-centric

\footnotetext{
${ }^{3}$ According to Pascale Casanova (CASANOVA, Pascale. The World Republic of Letters, tr. by M.B. DeBevoise, Cambridge/London: Harvard University Press, 2004, 34-40), nationalization and aestheticization ("depoliticization") govern any process of "invention" of a national literature. The time and the pace of these processes are the only divergent aspects among the various cultures.
} 
* (ORNEA, Z. Tradiţionalism şi modernitate în deceniul al treilea. Bucharest: Minerva, 1980.)

*(GUILLEN, Mauro F. “Modernism without Modernity: The Rise of Modernist Architecture in Mexico, Brazil, and Argentina, 18901940". In: Latin American Research Review, v. 39, n. 2, 2004: 6-34.) character, no approach of any of the three concepts can exclude the other two. More precisely, no thorough analysis of Romanian modernism can occur in the absence of a constant reference to the sociopolitical ideologies underlying this concept, to the historical framework that generated these ideologies and, last but not least, to Romania's rhythm of modernization in relation to other societies and cultures situated both in the neighboring and in other geographic areas. Nevertheless, until now, it seems this aspect had been observed only partially and fragmentarily, hence the necessity to critically and systematically revisit Romanian modernism. Since the complexity of this topic exceeds considerably the limits of an article, henceforth I shall approach only indirectly the extension of the concept (representatives, individual traits, scope, etc.) and I have chosen to focus on its intension, i.e. how Romanian literary criticism has pieced together this concept.

\section{Contextualizing Romanian modernism}

Let me begin with a series of preliminary clarifications on the creation of the concept of modernism in Romanian literature. Firstly, in a manner similar to most literary movements in Romania, modernism is a loanword, adopted along (mainly) French and (less) German lines at around 1900. The establishment and the application of the term in Romania gave rise to a number of problems undoubtedly derived from the many social, economic, political and cultural differences between Romania and Western countries, which, in fact, would become the object of numerous controversies in Romanian cultural media at the beginning of the $20^{\text {th }}$ century.* Thus, while in the West modernism emerged with the appearance of a vie moderne (Baudelaire's words), which meant industrialization, urbanization and secularization, the same material and social conditions were scarce in a peripheral, agrarian, rural country governed by archaic mentalities, as Romania was in the $19^{\text {th }}$ century and the beginning of the $20^{\text {th }}$ century. Hence, there were heated debates on the validity of the concept of modernism in Romanian culture, a concept that, at least until the beginning of the $20^{\text {th }}$ century, can be projected, as in Latin America's literary cultures, as a "modernism without modernity".* In this context, I also note that, until recently decades, Romanian critics chose to apply various Western definitions rather than to attempt their own 
approach of this "traveling concept", which would be adjusted to the local circumstances.

Secondly, the specific nature of Romanian culture does not exclude a series of interesting peculiarities regarding the emergence of its own modernism in relation to other (semi)peripheral literary cultures' modernisms. To this end, a comparison to Brazilian modernism may prove useful. ${ }^{4}$ Like in Brazil, in Romania, too, modernism emerged in the inter-war period, after a period of seeming literary decadence - the so-called "era of transition" from the end of the $19^{\text {th }}$ century and the beginning of the $20^{\text {th }}$ (approx. 18891918), which would roughly correspond to Brazilian "pre-modernism" (1895-1922); similar to Brazil, the assertion of modernism was experienced in Romania as an era of significant growth, if not even a "golden age" of national literature; like in Brazil, Romanian modernism emerged as an outcome of the innovating incentives from West- European artistic movements. Unlike Brazil, however, where modernism was welcomed by most of the intellectuals as a precious stimulus on the path of building a national identity, in Romania many inter-war writers read it as a cosmopolitan movement threatening the integrity of "national character". On the other hand, ever since before the First World War, Romania would already see the beginning of a series of original avant-garde endeavors, ${ }^{5}$ which became radical in the 1920s. This is why, whereas in Brazil modernism was a synthetic movement that assimilated traditionalist, regionalist, nationalist and avant-garde elements alike, in Romania modernism was given a hostile welcome both by traditionalism (as "too new"), and by the avant-garde (as "not new enough"). Furthermore, whereas Brazilian modernism was undertaken and theorized by critics and writers alike, Romanian modernism is first of all a creation of the critics, since most of the important writers of the inter-war age rejected vehemently such a classification of their

\footnotetext{
${ }^{4}$ For an overview of Brazilian modernism, see PONTIERO, Giovanni. "Brazilian Poetry from Modernism to the 1990s”. In: ECHEVARRÍA, Robero González, PUPO-WALKER, Enrique (eds.). The Cambridge History of Latin American Literature, vol. 3.: Brazilian Literature; Bibliographies. Cambridge: Cambridge University Press, 1996: 247-268; FARIA COUTINHO, Eduardo De. "Brazilian Modernism”. In: EYSTEINSSON, Astradur, LISKA, Vivian: Modernism, vol. 2. Amsterdam/Philadelphia: John Benjamins, 2007: 759-768.

5 The most representative case here is Tristan Tzara's, who only several years later would become one of the creators of Dada (cf. CERNAT, Paul. Avangarda românească şi complexul periferiei. Bucharest: Cartea Românească, 2007: 25-60).
} 
work. Finally, while regarding Brazilian modernism literary historians agreed there was a particular organic evolution (obvious in three phases: 1922-1930, 1930-1945 and 1945-c.1970), in Romania, like in the other Eastern European countries, the "natural" development of modernism was brutally halted after the Second World War, with communism ascension to power and, thus, of the Soviet socialist realism.

Thirdly, Romanian modernism is defined by a series of specific traits, determined by its own cultural tradition, two of which seem to be more pertinent. On the one hand, there are two historical "complexes" of Romanian literature, voiced in the verdicts by Vasile Alecsandri ("Every Romanian is born a poet", 1852), and by Nicolae Iorga ("Why we don't have our own novel?", 1890), which endorsed the cliché of the Romanian poetry's precedence over fiction and which led to a lyric genre clustering of the definitions of Romanian modernism. On the other hand, there is the requirement of the "autonomy of the aesthetic" which, in Romania, turned into an actual dogma, since the existence of literature as a specific discursive practice would be constantly at threat from various nationalist or social "tendencies" that attempted to control it. This led to a definition of Romanian modernism more from the viewpoint of its form, as rhetorical "technique" and less from the viewpoint of its literary content, as forma mentis or as Weltanschauung.

\section{Modernism in poetry: form without ideology (I)}

Considering the reasons mentioned above, I start by analyzing modernism in poetry. Generally, Romanian literary historians agree that modern Romanian poetry begins after the death of Mihai Eminescu (1850-1889), Romania's "national poet", through the emergence of the symbolist movement promoted by the former's main rival, Alexandru Macedonski (1854-1920) and asserted in the pages of the magazine Literatorul (1880-1919). Nevertheless, until the First World War, Romanian literature would continue to be dominated by Eminescu's epigones (before 1900), and later by two agrarian movements opposing modernity: sămănătorism and poporanism/ populism. ${ }^{6}$ Consequently, the term modern would begin

\footnotetext{
${ }^{6}$ Sămănătorism was promoted in the magazine Sămănătorull The Sower (19011910), led by Nicolae Iorga, while poporanism was backed up by the magazine Viața românească/ Romanian Life (1906-1916; 1920-1940), led until 1930 by G.
} 
to be used in Romanian literary press only around 1887, while its semantic specialization (as modernism) would materialize only after 1900.* Nonetheless, in the first two decades of the last century, this terminological pair refers to a mainly hostile environment, which means that they were used with rather pejorative implications. In Romania, modernism becomes a respectable literary movement only in the 1920s, and its accreditation and definition were linked to the critic E. Lovinescu, who promoted the new movement in the magazine Sburătorul/ Winged Spirit (1919-1922; 1926-1927) and in the debates held by its namesake literary circle. In Lovinescu's view, modernism is more than a "new" literary movement; it is the spearhead of an extended philosophical and sociological platform the critic developed thoroughly in his History of Modern Romanian Civilization. * Starting from Gabriel Tarde's concept of "imitation", Lovinescu stated here that societies and cultures develop only to a small extent through organic evolution; instead, they progress through mutations ("leaps") triggered by the adoption of material and spiritual structures of the more developed nations. According to Lovinescu, in the contemporary era, owing to the fast development of the means of communication, imitation would occur almost instantaneously and, thus, would impose the law of "synchronism" as a principle of development of modern cultures and societies. Based on this principle, Lovinescu claims the necessity of modernizing Romanian society through industrialization and urbanization, as well as the adoption of modernism as form of art keeping with the "spirit of the age".

This perspective was defined, only several years later, in the third volume of his History of Contemporary Romanian Literature (1926-1929), where the most significant part of inter-war Romanian poetry - particularly the canonical poets Tudor Arghezi (1880-

Ibrăileanu. Although the two directions had specific ideological differences, both of them promoted nationalism, rural themes and moral lessons of literature and displayed an anti-modernist attitude. For an overview of the Romanian literary ideologies at the end of the $19^{\text {th }}$-beginning of the $20^{\text {th }}$ century, see TERIAN, Andrei. "National Literature, World Literatures, and Universality in Romanian Cultural Criticism 1867-1947”. In: CLCWeb-Comparative Literature and Culture, vol. 15, n. 5, 2013 <http://docs.lib.purdue.edu/clcweb/vol15/iss5/12>.

${ }^{7}$ For the relations between Lovinescu's sociology and literary criticism, see TERIAN, Andrei. Teorii, metode și strategii de lectură în critica și istoriografia literară românească de la T. Maiorescu la E. Lovinescu. O abordare comparativă, București: Muzeul Național al Literaturii Române, 2013: 146-156.
* (OMĂT, Gabriela. "Modernismul românesc în date". In: OMĂT, Gabriela (ed.), Modernismul literar românesc în date (1880 2000) şi texte (1880 1949), vol. 1. Bucureşti: Romanian Cultural Institute, 2009: 51-78.)

* (LOVINESCU, E. Istoria civilizaţiei române moderne, 3 vol. Bucureşti: Ancora S. Benvenisti \& Co., 19241925.) 
* (LOVINESCU, E. Istoria literaturii române contemporane, vol. 3: Evoluția poeziei lirice. Bucureşti: "Ancora" S. Benvenisti \& Co., 1927: 324-430.)

* (BARBU, Ion. Evoluţia poeziei lirice după E. Lovinеscu (1927). In: OMĂT, Gabriela (ed.), Modernismul literar românesc, vol. 2, ed. cit.: 89.)

* (DUmitru, Teodora. "Modernismul - document şi fantasmă. Sursele modernismului românesc. Modernismul în concepţia lui E. Lovinescu". In: Cultura, n. 27 (431), 1 August 2013: 14-15.)

* (LOVINESCU, E. Istoria literaturii române contemporane, Vol. 3, ed. cit., 91.)

*(Idem, 91.)

*(Idem, 438.)

* (LEFTER, lon Bogdan. Recapitularea modernităţii. Pentru o nouă istorie a literaturii române. Piteşti: Paralela 45, 2000: 133-163.)
1967), Ion Barbu (1895-1961) and Lucian Blaga (1895-1961), as well as other authors, such as Adrian Maniu, Aron Cotruș or Al. Philippide - were placed in the category of "modernist poetry".* Nevertheless, while the ranks established by Lovinescu were quickly adopted at that time, the same did not apply to the meanings he had ascribed to the concept of "modernism" as such, which would remain a disputed term. The explanation of such a semi-failure relates firstly to the era's most important poets' reluctance to accept this notion; one of them even labeled modernism as an "insult".* On the other hand, Lovinescu himself had ascribed to modernism a series of opposing meanings. Without approaching the concept systematically, the critic defined modernism, in a span of only several years, both as (post)symbolism and anti-symbolism, as "pure" lyricism and anti-lyricism, as musicality and plasticity, as subjectivism and objectivism, as intellectualism and "imagism". * Finally, by proclaiming the "inutility of a disagreement on the poetic material",* Lovinescu limited modernism to a merely formal meaning and he created the premises of an artificial unification of the entire Romanian poetic field. Thus, the critic stated that contemporary lyric traditionalism - particularly the Orthodoxist one, promoted by the magazine Gândireal Thought(1921-1944), led by Nichifor Crainic, one of the main opponents of Lovinescu's ideology - would be, in fact, "a sămănătorism synchronized with the time's aesthetic requirements by a contact, at some poets as alert as the modernists', with Western stylistic devices, if not even with the Western sensitivity as such"; * similarly, Lovinescu kept the "extremist" - his label for the avant-garde - Romanian movements within the ranks of "latest modernist attempts". In both cases, the critic applied a formal (rhetoric) criterion, i.e., the use of specific "stylistic devices" (suggestion, ambiguity, syntax fragmentation, etc.), which led him to the forced invalidation of borders between the most important formulae of the Romanian inter-war poetry. Therefore, although they did contribute to the confirmation of the concept of modernism and inferred some of the traits of poetic modernity (lyricism, ambiguity, anti-mimesis etc.), neither Lovinescu, nor his disciples could provide a functional definition of this paradigm.*

For these reasons, to which it also added the boycott of modernism in the first phase of Romanian communism (1948-1965), characterized by the dictatorship of socialist realism, a more adequate circumscription of the concept is seen in Romania only 
toward the end of the 1960s, with the translation in Romanian of Hugo Friedrich's Structure of Modern Poetry, soon to become an authentic Bible of Romanian poetry criticism.* By defining modern poetry according to so-called "negative categories" (depersonalization, empty transcendence, fragmentariness, dislocation, etc.), Friedrich's book provided Romanian critics with the advantage of a clear and solidly articulated concept. However, his theory involved, at the same time, two significant disadvantages. Firstly, by proclaiming a "structural unity" of modern poetry, the German scholar would discourage rather than encourage Romanian critics' attempts to dissociate modernism from the competing poetic formulae. Secondly, in keeping with his method (a strictly stylistic one), Friedrich would also limit modernism to a purely formal element - or, at any rate, to one in which the artistic reality was deemed a mere effect of language. The outcome of these two premises (particularly of the latter) influenced both the faithful applications of Friedrich's theory in the 1970s and the 1980s and the attempts to outgrow his design. Thus, in the largest study, to this day, on Romanian poetic modernism, although systematically arguing (on almost 50 pages) against Friedrich's concept, Dumitru Micu does more than fail to propose an alternative concept of modernism; he also trivializes the term, mistaking it for novelty in general (any poetic formula would be "modern" in relation to another one) and thus deeming "modernist" the entire extent of valuable Romanian poetry in the 1880-1980 timespan, irrespective of formula and topic.* Nicolae Manolescu suggested one way to overcome this obstruction; he identified "two kinds of being modern" and he dissociated the "modernist" poetry as such from the poetic "avant-garde".* Nevertheless, aside from the fact that Manolescu outlines the avant-garde at least eccentrically (his concept covers the "historical" avant-gardes as well as Rimbaud, Lautréamont and Whitman), he perpetuates a purely formal concept of modernism and, thus, Lovinescu's preconception of traditionalism as an integral part of modernism from which the former would differentiate only by its themes, not by its "style".* Perhaps the boldest attempt of Romanian criticism to revise Friedrich's concept came from Gheorghe Crăciun, who stated that, although most of the works on modern poetry still operate on the concept proposed by the German scholar (where lyric modernity is reduced to a "reflexive" poetry based on symbol, obscurity, subjectivity, connotation
* (FRIEDRICH, Hugo. Die Struktur der modernen Lyrik: Von Baudelaire bis zur Gegenwart. Hamburg: Rowohlt, 1956; Romanian translation: Structura liricii moderne de la jumătatea secolului al XIX-lea până la mijlocul secolului al XX-lea. Trans. by Dieter Fuhrmann. Bucureşti: ELU, 1969.)

*(MICU, Dumitru. Modernismul românesc, 2 vol. Bucureşti: Minerva, 19841985.)

* (MANOLESCU, Nicolae. Despre poezie. Braşov: Aula, 2002 (1987): 134-140.)

*(Idem: 177-182.) 
* (CRĂCIUN, Gheorghe. Aisbergul poeziei moderne, with an Argument by the author, afterword by Mircea Martin. Pitești: Paralela 45,2002 .)

* (LOVINESCU, E. Istoria literaturii române contemporane, vol. 4, ed. cit.: 216.) and destruction/overcoming of immediate reality), modern poetry would include two additional dimensions: a "ludic-experimental" one, discernible in avant-garde poems, and a "transitive" one, relying on clarity, denotation, objectivity and description of immediate reality, which, starting from Whitman, Pound and Pessoa, and ending with Montale, Williams and Ponge, had already formed its own tradition. ${ }^{*}$ Crăciun's typology may be correct (I am not going to analyze it here); however, I cannot overlook the fact that it continues to circulate at the beginning of the 2000s, even if on a different level of the spiral, the clichés E. Lovinescu had established nearly a century before: on the one hand, irrespective of their differences, both "reflexive" poems and "transitive" and "ludic-experimental" ones are seen as subdivisions of modernism broadly speaking; on the other hand, this "modernism" is again defined formally, i.e. rhetorically, by neglecting the diversity of values and attitudes that may stay obscured underneath its formula.

\section{Modernism in fiction: form without ideology (II)}

While Romanian critics focused often on poetic modernism, despite its inaccuracies and limitations, the same cannot be said about prose writing and mainly novel writing. This omission can be explained by the fact that E. Lovinescu himself, the patriarch of Romanian modernism, limited the direction of this concept to poetry. Thus, in the fourth volume of his History of Contemporary Romanian Literature (1928), the critic invokes Ferdinand Brunetière's evolutionist principle, according to which the "natural" development of each literary genre occurs in the sense of its own "essence" (lyric and subjective essence for poetry; epic and objective for fiction). Hence, given these circumstances, the evolution toward lyricism and subjective of the modernist fiction would be a "mixed" and "reactionary" tendency, "opposed to the direction of the genre's evolution as such".* This position indicates more than a specific type of aesthetic conservatism; it is also suggestive of an exercise through which the critic tried to discredit the narrative production of the rival traditionalist groups, particularly that of sămănătorism and poporanism, which relied on lyricism in the evocation of a patriarchal atmosphere and on compassion in the description of the peasant's condition. In any case, Lovinescu's approach is not only reductive; it is downright flawed, as noted by one of his 
commentators at that time, the novelist Mihail Sebastian (19071945), who drew attention to the immense distance that separates the lyricism of traditionalist rural novel, idealizing the pure and uncorrupted peasants, from the modern, analytical lyricism in the line of Proust.* In fact, Sebastian was one of the few Romanian writers of the inter-war period who tried to apply modernism to fiction, even if his observations had carried almost no echo among his contemporaries. ${ }^{8}$ However, in the best known epic manifesto of the time - Noua structură si opera lui Marcel Proust (1935) -, Camil Petrescu (1895-1957), a writer considered the main representative of modernization in the Romanian novel, avoided ostentatiously any discussion of modernism (a concept that, in fact, he had repudiated in several articles published at the end of the 1920s). As for the literary critics and historians of the age, they chose either to operate on the thematic distinction rural $v$ s. urban fiction, ${ }^{*}$ or to classify each novelist according to their narrative "manner" or "technique" (e.g., "Proustians", "Gidians" etc.).*

These uncertainties will continue, to a certain extent, in the post-war era, although starting in the 1960s the analysis of prose also begins to use the term of "modernism". Similarly to what happened in poetry, a significant incentive was provided here by translations, particularly that of R.-M. Albérès's History of Modern Novel, ${ }^{*}$ which, in Romanian criticism, had a role somewhat analogous to Hugo Friedrich's monograph (including the artificial dilation and unification of modernism, since for the French critic all the important novelists, from Balzac to Robbe-Grillet, were "modern"). In this context, an important step in the configuration of the concept of narrative modernism in Romania was the publication of Nicolae Manolescu's extensive essay on the Romanian novel (1980-1983). According to the critic, the evolution of this genre is divided among three forms and ages he labels Doric, Ionic and Corinthian, thus borrowing Albert Thibaudet's concepts, but redefining them in the terms of structural narratology and supplementing them with a new category.* From among these, the Doric largely corresponds to Balzac's model, with an omniscient narrator, typology and socioeconomic conflict; the Ionic is the outcome of Proust's revolution: the narrator becomes a character himself, heroes ditch their fixed out-
* (SEBASTIAN, Mihail. "E. Lovinescu, Istoria literaturii române contemporane, vol. IV: Evoluţia prozei literare" (1928), In: OMĂT, Gabriela (ed.), Modernismul literar românesc, vol. 2, ed. cit. 147-151.)

* (LOVINESCU, E. Istoria literaturii române contemporane, vol. 4, ed. cit.)

*(CĂLINESCU, G. History of Romanian Literature. Trans. by Leon Levițchi. Milan: Nagard, 1988 (1941).)

* (ALBÉRÈS, R.-M. Histoire du roman moderne. Paris: Albin Michel, 1962; Romanian translation: Istoria romanului modern. Trans. by Leonid Dimov, Foreword by Nicolae Balotă. Bucureşti: ELU, 1968.)

* (MANOLESCU, Nicolae. Arca lui Noe. Eseu despre romanul românesc. Bucureşti: 100+1 Gramar, 2004 (19801983): 732-733.)

\footnotetext{
${ }^{8}$ For Sebastian's ideas on the "modern novel", see IOVĂNEL, Mihai. Evreul improbabil: Mihail Sebastian - o monografie ideologică. București: Cartea Românească, 2012: 81-87.
} 
* (MANOlescu, Nicolae. Istoria critică a literaturii române. Cinci secole de literatură. Pitești: Paralela 45, 2008: 455-882.)

*(Idem: 555-557.)
* (CĂRTĂRESCU, Mircea. Postmodernismul românesc. Afterword by Paul Cornea. Bucureşti: Humanitas, 1999: 272, 293.) lines and the conflict has an inner nature; finally, while these two categories continue to share a more or less "realist" perspective, the Corinthian is governed by different laws: it is not the narrative perspective, but the subversion of the mimesis (through myth, symbol, irony and parable) that matters. Nevertheless, apart from the fact that, as with poetry, Manolescu's classification is built on a strictly formal criterion (i.e., the relationship between narrator and characters or between author and represented world), it is far from solving the problem of modernism in the Romanian novel. One first hindrance seems to be that, while in Western literatures the three types indicate three successive "ages" of the novel, in Romania, because of the development delays, they occur almost simultaneously.* In Romanian literature, the most important novels of the 1920s and of the 1930s cover equally the Doric (Liviu Rebreanu, Ion, 1920; Mihail Sadoveanu, Baltagul, 1930; G. Călinescu, Enigma Otiliei, 1938), the Ionic (Hortensia Papadat-Bengescu, Concert din muzică de Bach, 1927; Camil Petrescu, Patul lui Procust, 1933; Mircea Eliade, Maitreyi, 1933) and the Corinthian (Mateiu I. Caragiale, Craii de Curtea-Veche, 1929; M. Blecher, Întâmplări din irealitatea imediată, 1936; Tudor Arghezi, Cimitirul Buna-Vestire, 1936). On the other hand, the relationship of the three categories with modernism is kept ambiguous, given that the said term is not mentioned anywhere in Manolescu's essay, while the word "modern" is indicative, for him, of a mere undetermined innovation. Furthermore, when nearly three decades later the critic reconsiders his categories' relationship with modernity, he can offer only an ambiguous reaction. For, in his Critical History of Romanian Literature (2008), Manolescu places, on the one hand, the entire Romanian novel of 1889-1948 in the category of modernism;* and, on the other hand, he evicts it insidiously therefrom, since he labels the Doric and Ionic novels as "realist", while he prudently calls "postrealist" the Corinthian one.*

Nevertheless, Manolescu's taxonomy has stimulated the emergence of other attempts to classify the Romanian novels of the first half of the $20^{\text {th }}$ century. From among these, a significant approach is Mircea Cărtărescu’s overview on Romanian post-modernism, which assimilates the Doric novel to the traditional ("realist") one, the Ionic novel with the modernist, and the Corinthian with the postmodern one.* Cărtărescu's solution seems simple and elegant; this is why it has been largely adopted by Romanian curricula in 
secondary education. However, the issue here is that - because of the use of a purely formal principle - it involves the existence in Romania, since the 1920s-1930s, of a literary paradigm which is set to occur, in fact, only half a century later, namely, postmodernism. A fact suggestive of the inaccuracy attached to Cărtărescu's equations rather than of the precociousness of Romanian literature. On the other hand, Manolescu's classification has also been the starting point of a polemic study by Sorin Alexandrescu, ${ }^{*}$ who notes that the three "forms" of the inter-war Romanian novel have a common denominator: they outline a so-called "aesthetic modernism", based on the convergence between the principle of the autonomy of the aesthetic and the values of liberal democracy. Contrary to this paradigm, he points out the existence of an "ethic modernism", promoted by the magazine Cuvântul/Word and by the Criterion Group (Mircea Eliade, Emil Cioran, Mihail Sebastian, Eugen Ionescu, etc.), by the Romanian avant-garde movements, as well as by other cultural groups (e.g., the new leading team of the magazine Viața românească, which had abandoned the pre-war aggressive poporanism); all these challenge both the supremacy of the aesthetic principle in literature and the supremacy of liberal values in politics. Alexandrescu's hypothesis is challenging, but it tends toward an overemphasis opposed to Cărtărescu's: while the latter overstated, in line with Manolescu, the formal criterion, the former, who joins the same category the Doric, the Ionic and the Corinthian, cancels it and reduces modernism to a mere ideological attitude. On the other hand, the heterogeneous character of the concept of "ethic modernism" indicates a vital aspect to the understanding of literary modernity, which Alexandrescu, however, leaves open: namely that not all oppositions against modernity occur in the same way and in the name of the same values.

Anti-modernism: ideology without form

During the last decade, there have been several attempts to solve the issues attached to circumscribing Romanian modernism by introducing new concepts. Thus, Caius Dobrescu has proposed a segmentation of modernism in two successive ages: "conservative modernism' generally means the fin-de-siècle literary experiments (although the term may seem slightly paradoxical, because it denotes, in fact, the entire period of 1880-1918). By 'radical
* (ALEXANDRESCU, Sorin.

"Romanul românesc interbelic: Problema canonului". In: Privind înapoi, modernitatea. Bucureşti: Univers, 1999: 125-148). 
* (Dobrescu, Caius Revoluţia radială. O critică a conceptului de postmodernism dinspre înţelegerea plurală şi deschisă a culturii burgheze. Braşov: Editura Universităţii "Transilvania”, 2008: 319.)

* (CERNAT, Paul. Modernismul retro în romanul românesc interbelic. Bucureşti: Art, 2009: 12.)

* (COMPAGNON, Antoine. Les Antimodernes: De Joseph de Maistre à Roland Barthes. Paris: Gallimard, 2005; Romanian translation: Antimodernii: De la Joseph de Maistre la Roland Barthes. Trans. by Irina Mavrodin and Adina Diniţoiu. Foreword by Mircea Martin. Bucureşti: Art, 2008.) modernism' I mean [...] the historical avant-garde and 'literature of commitment"'.* Nevertheless, the distinction between the two modernisms is controversial both at the level of Romanian literature and in literature in general. It does not have a chronological support ("conservative modernism" does not end with the First World War, and it includes many nostalgic projects emerging before this historic threshold), nor does it have a typological one (a large part of Romanian and European literature rejects social militancy and the avant-garde, which does not mean that it becomes conservative). From this point of view, a more striking approach is the concept of "retro-modernism", launched by Paul Cernat and described as the "blend of nostalgic solidarity and critical distance from the conventions of a recent enough age ..., the aestheticizing livresque assumption of the 'desuetude' and of the 'anachronic' relating to the literary form also, the retrieval of an atmosphere that transfigures - through the poetic, the imaginary and the myth - the realist-social mimesis, the preeminence of illusion before reality". ${ }^{*}$ Cernat's "eclectic typology", however (which includes novelists such as G. Ibrăileanu, Mateiu Caragiale, G. Călinescu, Mihail Sadoveanu, Ionel Teodoreanu and Mircea Eliade), is not founded on solid ground; from among the so-called "retro-modernists", some are only "retro", but not "modernists" (Mihail Sadoveanu or Ionel Teodoreanu, who disseminate obsolete narrative techniques), while others are "modernists", but not "retro" - e.g., Mircea Eliade, in whose "old world" of the novel Domnişoara Christina (1936) the retrospective gesture is not automatically followed by its nostalgia.

The term that gained widespread popularity in recent Romanian criticism is "anti-modernism", which became established especially owing to the translation in Romanian of Antoine Compagnon's Les Antimodernes.* Nonetheless, before I consider the Romanian applications of this concept, I think it is important to make a few brief comments on the volume as such. Firstly, Compagnon's book concerns exclusively French culture, ignoring both the forms of manifestation and the previous analyses of "anti-modernism" in other cultures, although some of the latter anticipate certain of his ideas and would have provided his analysis additional weight through the opening of a broader comparative context. ${ }^{9}$

\footnotetext{
9 See, for example, JACKSON LEARS, T.J. No Place of Grace: Antimodernism and the Transformation of American Culture (1880-1920). New York: Pantheon Books, 1981.
} 
Secondly, Compagnon's definition elicits several questions relating to its consistency: if, as stated by the French critic, "the real antimoderns are, at the same time, moderns, even perpetually modern, or moderns against their will" and, moreover, if "the anti-moderns [...] are only moderns, the true moderns", ${ }^{*}$ then the very analytical utility of the "anti-modern" as concept is to be doubted. ${ }^{10}$ On the other hand, even though it is acceptable that the "modern" antimoderns represent a typological category distinct from the "modern" moderns, Compagnon does not provide any clear criterion to help dissociate the former ("anti-moderns in the interesting [? - my emphasis], modern sense of the word") from the "mere" traditionalists, although he seems to believe firmly in such a distinction.* Finally, through the limitation to a substantivization of the adjective (les antimodernes/ the anti-moderns), Compagnon indulges in a comfortable ambiguity, without mentioning whether, in his text, the prefix anti- concerns (cultural) modernism, (historic) modernity or both: indeed, he discusses mostly writers and critics, but discusses them exclusively from the viewpoint of their ideological attitudes, without reference to the form of their discourse.

These flaws in Compagnon's theory can also be identified, to various extents, at his Romanian disciples. From among them, Oana Soare applied most faithfully the theory of anti-modernism; she borrows not only the French theorist's perspective, but also its limits and ambiguities. Thus, Soare relates only briefly to the particular conditions of Romanian culture in relation to the French one. At the same time, she approaches only the ideological positions of Romanian writers, without any notes on the extent to which they

\footnotetext{
${ }^{10}$ The definition of modernism/modernity as a critical and self-reflexive age - or, to be more exact, of (cultural) modernism as criticism of (historic) modernity - is one of the common places of the theory of modernity in the last half of century: "what defines cultural modernity is its outright rejection of bourgeois modernity, its consuming negative passion" (CALINESCU, Matei. Five Faces of Modernity, ed. cit.: 42). In fact, Calinescu has expresed early his doubt on the originality of Compagnon's theory, stating that "Compagnon's 'five paradoxes' [in COMPAGNON, Antoine. Cinq paradoxes de la modernité. Paris: Seuil, 1990, which could be seen as a draft of Les Antimodernes] are not far from my earlier 'five faces' of modernity, although his formulations differ on occasion and he adds a substantial discussion of artistic currents and trends over the last century" (CĂLINESCU, Matei. "Modern, Modernism, Modernization: Variations on Modern Themes". In: BERG, Christian, DURIEUX, Frank, LERNOUT, Geert (eds.). The Turn of the Century: Modernism and Modernity in Literature and the Arts. Berlin/ New York: Walter de Gruyter, 1995: 39).
}

* (COMPAGNON, Antoine. Les Antimodernes, ed. cit.: 7-8.)

* (COMPAGNON, Antoine. Les Antimodernes, ed. cit.: 9.) 
* (SOARE, Oana. Modernitate şi reacţii antimoderne în cultural română. Bucureşti: Editura Muzeului Naţional al Literaturii Române, 2013: 33.)

*(Idem: 46.)

* (ALEXANDRESCU, Sorin. "Romanian Modernism and Anti-Modernism". In: VAJDOVÁ, Libuša; BŽOCH, Adam (eds.). Controversial Modernity. Bratislava: Slovak Academic Press, 2011: 17-35.) actually reverberate in the form of their discourse and particularly in their literary work. This is why the greatest part of her approach does not even consider poets or novelists, but rather the three critics and ideologists who defined the structure of Romanian literary canon from the 1870 s to the 1930s: T. Maiorescu, G. Ibrăileanu and E. Lovinescu. Last but not least, the concept of anti-modernism is stretched to such a degree that it seems to incorporate modernism itself. This aspect is most obvious in the analysis of Camil Petrescu's ideology (who had been labeled a "champion of modernism" by the previous literary historiography, but who, in Soare's opinion, is "a dual, Janus Bifrons profile of the anti-modern modern"*), as well as of E. Lovinescu's, at whom modernism is seen as a simple "bovaristic projection of a spirit who had initially rejected modernity".* From this viewpoint, Sorin Alexandrescu's more recent analyses are more challenging, for they further to the contact with Compagnon's theory, updating his opposition between the "esthetic" and "ethic modernism". Thus, Alexandrescu continues to identify the "aesthetic modernism" with a "liberal (ideological) block", but distinguishes within the "ethic modernism" no less than six additional cultural "blocks": agrarian, traditionalist, "anti-modern", right-wing extremist, left-wing extremist and avant-gardist.* Notwithstanding fact that the last three of these trends are merely listed and not analyzed (which raises questions about the accuracy of the classification, because a large part of the Romanian avant-garde was, in fact, left-wing extremist, just as a part of the so-called "anti-moderns" - which the author links to the Criterion Group - were actually right-wing extremists), Alexandrescu's approach ends this time too at the political and ideological aspects of the concerned directions, without almost any mention of their literary consequences and of the discourse structures that express the said attitudes.

\section{Toward a systematic reconstruction of Romanian literary modernity}

Therefore, previous approaches of modernism in Romanian literature display three significant shortcomings: (a) in general, Romanian critics disseminate a reductive vision of modernism, which limits it to either a formal approach (as literary "technique") or to a substantial one (as ideological attitude); (b) a result of this 
perspective is the emergence of a non-differentiated concept of modernism, a sponge-concept that tends to absorb any adverse reactions; (c) even when they do identify the presence of an "other-thanmodernism", Romanian critics tend to place it under a generic antimodernism, irrespective of the degree or the direction in which it challenges modernism. Despite this situation, I believe such obstacles can be overcome, provided that, on the one hand, we consider both the form and the vision of literary discourse and, on the other hand, we distinguish more diligently the cultural positions from where the critique of modernism is advanced. For example, I find it essential to distinguish between the critique of modernity as type of society that encourages appearances and superficiality (in Camil Petrescu's novels) and the negation of modernity through the projection of an atemporal and archetypal Moldavia (in Mihail Sadoveanu's novels). Likewise, I think it is important to distinguish this regressive negation of modernity from what could be called the progressive negation of modernity (by envisaging a "new man" and a society based on vitality rather than on the corrupt bourgeois values, in Mircea Eliade's novels). For while the first one engenders a critical and self-reflexive modernism, the second one disseminates an obvious anti-modernism, while the last one projects an ultra-modernism that counteracts a potential "suspension" of the project of modernization. ${ }^{11}$ These positions are encountered not only in the novel, but also in Romanian inter-war poetry, in which the attachment to pre-modern collective values (shared by the rural and religious "traditionalist" poets - e.g., Vasile Voiculescu and Ion Pillat) should be dissociated from the assumption of individualism as an outcome of secularization and of the modernity crises (e.g. Tudor Arghezi and George Bacovia), as well as from the attempt to transcend the limits of modernity with the help of the latest technological achievements or by inventing a new mystique (in the avantgarde poetry). Therefore, I believe Romanian literary modernity of the first half of the $20^{\text {th }}$ century could be successfully described via three complementary "faces":

\footnotetext{
${ }^{11}$ An important suggestion to this end comes from Jacques Maritain, the first theorist of the "anti-modern", who had warned that "what I call here anti-modern may equally be called ultra-modern" (MARITAIN, Jacques. Antimoderne, revised and augmented edition. Paris: Revue des Jeunes, 1922: 14), subsequently describing his own idea: "Anti-modern in relation to the errors of the present, it is ultra-modern in relation to the truths concealed in the ages to come" (Idem: 16).
} 
1. Anti-modernism, promoted mainly by the group around the magazine Gândirea and represented by writers such as Liviu Rebreanu, Mihail Sadoveanu, G. Călinescu, Lucian Blaga (as a poet, but also as a philosopher of culture), Vasile Voiculescu and Ion Pillat. Ideologically, this direction means a conservative critique of liberal bourgeois democracy in the name of the nostalgia for a traditional, agrarian, orthodox society loyal to the collective and archetypal values of a supposed "Romanian spirit". In their novels, the anti-moderns prefer Balzac's formula of a Doric realism and a rural background, while their poetry is characterized by the ostentatious growing of (apparently) obsolete species, such as the elegy, the hymn or the psalm. Although, in general, it rejects modernism, this direction is fully aware of its existence as a reaction to modernity.

2. Modernism, promoted mainly by the magazine Sburătorul and represented by writers such as Hortensia Papadat-Bengescu, Camil Petrescu, Anton Holban, E. Lovinescu and (partially) Tudor Arghezi. Ideologically, this direction is characterized by a liberalism subordinated, generally, to bourgeois individualism and to the benefits of "modern life". In their novels, the modernists describe an urban background by adopting the interiorized, Ionic perspective of French psychologism (especially Proust's and Gide's), while their poems draw both upon Baudelaire's and Rimbaud's moral tearing and upon Mallarme's and Valéry's aesthetic purism. Although, in general, it adheres to modernity as the historical age of individual emancipation, modernism does not exclude a self-critical and selfreflexive awareness.

3. Ultra-modernism, promoted especially by the Criterion Group (Mircea Eliade, Emil Cioran, Mihail Sebastian, Eugen Ionescu, etc.) and by the many avant-garde magazines (which enjoyed contributions from Ion Vinea, Ilarie Voronca, Geo Bogza, Gherasim Luca, Gellu Naum, etc.). Ideologically speaking, this direction proclaims the failure of liberal democracy, either from the viewpoint of a fascist-tinged new spirituality (Criterion Group), or from that of a revolutionary ideal with an anarchic-communist touch (the avant-garde). In their novels (represented mainly by the Criterion Group), the ultra-modernists adopt frequently the essay, symbolic and parabolic formula to describe the utopia of a spiritual rebirth; in their poetry (represented mostly by the avant-garde), they choose to de-structure any literary form, in order to suggest 
the "permanent revolution". In both alternatives, the ultra-modernists look at modernity as a necessary, but transitory historical stage which they need to overcome.

I would add two observations on this classification. Firstly, beyond the fact that it attempts to solve the three taxonomic hindrances mentioned, it also strives to reflect the consistency and the coherence of the most important inter-war Romanian literary groups (Gândirea, Sburătorul, Criterion, the avant-garde, etc.). Indeed, as stated by Reinhart Koselleck, "there is always a gap between the historical reality and its linguistic representation, which leads invariably to the rewriting of a written history at a certain point in time".* I believe, however, that a literary historian must not give in to revisionism too easily; although at times it may seem to lead to spectacular results, there are many cases when revisionism tends to make the past even more opaque. For this reason I have attempted, through the above-mentioned concepts, to ply specific typological traits on the main centers of power in Romanian inter-war literature; otherwise, the positions and ideas so stubbornly defended by the intellectuals of the age could seem incomprehensible now. Secondly, it may be redundant to add that the concepts I proposed are scale downs and one should not expect them to match perfectly the options of Romanian writers at the beginning of the $20^{\text {th }}$ century. On the contrary, from this point of view there are significant contradictions; such is the case of Ion Barbu, who, although he began his literary activity in the magazine Sburătorul and was considered by Lovinescu one of the pillars of Romanian poetic modernism, made haste to move away from this paradigm by proclaiming the artistic supremacy of an "anti-modern” form (the Pindaric ode), as well as by expressing his admiration toward an "ultra-modern" political regime (Hitlerism). I am afraid, however, that in such cases the writers are to blame rather than my concepts.

Andrei Terian é Professor Associado da Universidade Lucian Blaga de Sibiu e Pesquisador Sênior III no Instituto G. Călinescu de História Literária e Teoria da Academia Romena de Bucareste. É autor dos volumes $G$. Călinescu: A cincea esență (2009), Critica de export: Teorii, contexte, ideologii (2013), e coautor de Diç̧ionarul general al literaturii române (7 vol., 2004-2009) e de Cronologia vieţii literare românești. Perioada postbelică
${ }^{*}($ KOSELLECK, Reinhart. Begriffsgeschichten: Studien zur Semantik und Pragmatik der politischen und sozialen Sprache. Mit zwei Beiträgen von Ulrike Spree und Willibald Steinmetz sowie einem Nachwort zu Einleitungsfragmenten Reinhart Kosellecks von Carsten Dutt. Frankfurt am Main: Suhrkamp, 2006: 70). 
(10 vol., 2010-2012). Publicou ainda cerca de 50 artigos em revistas internacionais "CLCWeb - Comparative Literature and Culture", "World Literature Studies", "Slovo", "Primerjalna književnost", "Interlitteraria" etc., bem como em revistas acadêmicas romenas. A pesquisa deste artigo foi financiada pela Autoridade Romena Nacional para Pesquisa Científica (CNCS-UEFISCDI), código PN-II-RU-TE-2012-3-0411. E-mail: <andrei.terian@ulbsibiu.ro>. 